\title{
Embodiments of the Sovereignty of the Republic of Indonesia under the Immigration Control
}

\author{
Muh. Asri Wahyuddin \\ Doctoral Student in Departement of Law, Universitas Muslim Indonesia \\ e-mail: masriwahyudin@gmail.com
}

\begin{abstract}
The nature of immigration control over the misappropriation of visas and residence permits in Indonesia in the framework of the operationalization of a selective policy of immigration law so that foreigners residing in Indonesia have limitations both in terms of their immigration clearance and their activities. The essence of oversight in order to uphold the sovereignty of the Republic of Indonesia as a jurisdiction, namely: jurisdiction to prescribe, jurisdiction to adjudicate and jurisdiction to enforce. Basically the main objective of foreign control is to protect the people and the sovereignty of the State. Foreigners who do not bring benefits and can jeopardize order should be prevented from entering the territory of Indonesia.
\end{abstract}

Keywords : embodiments, sovereignty, immigration

\section{INTRODUCTION}

Geographically the territory of the Republic of Indonesia is very strategic, which is located in the equator and spread between two continents of Asia and the continent of Australia and two oceans, namely the Indonesian Ocean and the Pacific Ocean. Indonesia is the largest archipelagic country in the world consisting of approximately 17,590 islands with an area of 18 million square kilometers.

The geographical position of In ndonesia and various natural, social and cultural resources so that the presence of foreigners within the Indonesian state is an unavoidable fact in its development. However, the presence of foreigners who entered the territory of the state of Indonesia in addition to providing many advantages there is also a negative value because of disruption of security and cause harm to the interests of the state of Indonesia.

The flow of immigrants in the contemporary era is a phenomenon in the world today due to many factors, such as ideological, political, economic, social, cultural, security, natural disasters, environmental factors and other driving factors and influences that cause the migration of people to continue with an ever-increasing quantity.

Responding to the phenomenon of foreigners from various countries who enter Indonesia to seek a profit requires that Immigration as one of the government institutions should be a guarded border in the context of foreign control and supervision. Oversight of foreigners who become obligations and responsible in the process of supervision not only 
on the intersection of the entry of foreigners, but the most fundamental is the supervision of the movement of foreigners in the field while in Indonesia. The need for field supervision for foreigners due to the many deviant behaviors perpetrated by foreigners such as visa abuses and residence permits. As the data of the Directorate of Immigration Investigation and Immigration in performing the functions of supervision and enforcement of immigration law from January to December 2013 have carried out Immigration and Pro Justice Action Acts against foreigners who commit immigration or criminal offenses. Immigration Administration Action, especially the deportation of foreign nationals who have violated immigration regulations, namely Law Number 6 Year 2011 on Immigration as many as 2011 and Pro Justice in 17 Immigration Cases either in prosecution process or have been submitted to court (P21) And get a verdict. The case contained in the data, sebahagian is a case of abuse of visa and residence permit.

Other data, such as data from the Directorate General (DG) of foreign citizens who enter in Indonesia, not all foreigners who are in Indonesia committed violations. Even when compared with the number of foreigners entering Indonesia, the number of violations tends to be small. They noted, until December 2014, the number of foreigners who enter through 56 doors connected Border Control Management (BCM) as much as 8.9 million. That number rose in 2016 at 9.3 million. During 2016, the Directorate General of Immigration recorded 341 immigration violations committed by foreign nationals. The offenses were dominated by Chinese citizens, 126 people, Nigeria 34, and Bangladesh as many as 27 people. Of the types of offenses committed by foreigners are related to visa abuse and residence permit.

Supervision of foreigners at least includes three things: supervision before entering the Territory of Indonesia, Supervision while in the territory of Indonesia, and Supervision when going out of the territory of Indonesia. In the context of this discussion, we will only discuss the second thing that Supervision while in the territory of Indonesia. Meanwhile, from the aspect of immigration supervision function, there are two kinds of supervision, namely admistrative supervision and field supervision. Administrative oversight related to immigration documents such as visas, residence permits and others. While the field supervision is done in order to match the administrative data with the reality in the field as well as the supervision of the activity while in the territory of Indonesia.

Of the two immigration supervisory functions mentioned above, there are at the Immigration Check (TPI) and the field, but from the reality aspect, the field supervision is not running effectively due to lack of personnel. In addition, the regency / municipality oversight team (PORA) that acts as a foreigner control also does not run maximally 
because they do not understand and understand related to Law no. 6 Year 2011 Immigration and type of violation of visa and residence permit. The effects of such misunderstandings resulted in weak supervision of foreigners at the district / city level.

Establishment of a foreign-level oversight team at the district / city level is important, but the formation is not merely shaped but should be given knowledge of the immigration laws primarily concerning the enforcement of foreigners to functionally perform their duties. The establishment of the Pora team is also a constitutional mandate in order to coordinate the supervision of foreigners in the region as mentioned in article 193 of Government Regulation (PP) no. 31 of 2013 on Immigration. In this PP is allowed to establish a Supervisory Team of foreigners up to the district level ie District / City and District. While the membership consists of agencies and / or government agencies in the region.

The timing of the team is very important, especially to oversee the presence of foreign nationals (WNA) in the country. Moreover, the current Economic Community of Asean (MEA) and the enactment of Presidential Regulation Number 21 of 2016, dated March 2, 2016, which sets visa free travel to Indonesia to 169 countries, so that more and more foreigners come to this country. With the presence of Pora team which aims to increase synergy and role of institutions and related institutions in conducting foreign supervision in accordance with their duties and functions, and actively increase the intensity of concentration and collaboration activities in the field. Considering the problem of border crossers is very complex and requires the cooperation of all elements of government, society and business actors, it is necessary a forum and mechanisms that are mutually agreed on in terms of supervision of cross-borderers, especially foreigners.

\section{ANALYSIS AND DISCUSSION}

\section{Immigration Control Philosophy}

Immigration philosophy in immigration control function as a method of developing the implementation of work within the scope of immigration personnel, then the administrative component should also be the main concern. It can be seen that the development of supervision in one of the developed countries such as the Netherlands, as a result of the aspect of professional supervisory contributions, seen as the goal of two-dimensional integration, can be illustrated about the handling of goal setting in oversight practices, such as the difference between the main control object (the professional implementation dimension) And the secondary object (the dimension of how supervision learns the implementation professional) such as the nature of the monitoring system, responds to the basic conditions required for supervision, the implementation 
process under supervision, streamlines the overall structure in the oversight process and considers the guiding framework of the superiors' intervention section within the scope of immigration.

Essentially immigration is a series of activities in the provision of services and law enforcement and security of traffic out of every person from and into the territory of the Republic of Indonesia, and supervision of the presence of foreign citizens in the territory of the Republic of Indonesia. ${ }^{1}$

Oversight of foreigners as a series of activities is basically initiated and conducted by representatives of the Republic of Indonesia abroad when receiving visa applications, Subsequent supervision is carried out by immigration officials at TPI, when immigration officials with their autonomous authority decide to refuse or grant entry permits, and After the foreigner is granted an entry permit, then is granted a residence permit which is in accordance with the visa it holds, then the supervision turns to ${ }^{2}$

The established immigration procedure is the operationalization of a selective policy of immigration law so that foreigners residing in Indonesia have limitations both in terms of their immigration clearance and their activities. Immigration Control includes immigration law enforcement where in the implementation of immigration duties the whole rule of immigration law is upheld to every person who is within the jurisdiction of the Republic of Indonesia be it Indonesian citizen or foreign citizen.

The concept of oversight does not only play in the realm of foreigners only when professional surveillance systems are to be achieved. The achievement of the quality of supervision on foreigners shall automatically the officer in charge of such supervision should always be supervised, as it does not require the possibility of weakness of a supervisory system against foreigners due to the internal immigration game itself between the officer and the foreigner related to the misuse of the visa and permit stay. ${ }^{3}$

In accordance with Law No. 6 of 2011 on immigration of services and supervision in the field of immigration carried out based on collective principles. Based on this principle, only foreigners can benefit the welfare of the people, the nation, and the State of Indonesia and do not endanger the security, order and hostility towards the people and the Unitary State of the Republic of Indonesia based on Pancasila and the 1945 Constitution permitted to enter or exit territory Indonesia. In order to realize the selective principle, it is necessary to supervise foreigners. This supervision is not only when they enter, but as long as they are in the territory of Indonesia including its

\footnotetext{
1 M. Iman Santoso, 2004, Persfektif Imigrasi dalam Pembangunan Ekonomi dan Ketahanan Nasional. Jakarta: Universitas Indonesia Press, hlm. 21.

${ }^{2} /$ bid., hlm., 21

${ }^{3}$ Bibit Samad Rianto, 2006, Pemikiran menuju Polri yang Profesional, Mandiri, Berwibawa, Dan Dicintai Rakyat. Jakarta: PTIK Press, hlm. 25.
} 
activities. Immigration controls include both administrative immigration law and immigration crime.

a. Immigration control is regulated in Law Number 6 Year 2011 on Immigration, namely Article 66 paragraph (2) determined Immigration Control includes:

b. Supervision of Indonesian citizens who request travel documents, exit or enter the Territory of Indonesia, and which are outside the Territory of Indonesia; and

c. Supervision of foreigners traffic entering or leaving the Territory of Indonesia and supervising the presence and activities of Foreigners in the Territory of Indonesia. mplementing Immigration Controls on foreigners shall be determined in Article 68 paragraph (1) that the Immigration Control of Foreigners shall be carried out at the time of Visa, entry or exit application, and the granting of a residence permit shall be conducted by: collection, processing and presentation of data and information; Foreigner subject to Penangkalan or Prevention;

d. Supervision of the existence and activities of Foreigners in the Territory of Indonesia;

e. Taking photos and fingerprints; and

f. Other activities that may be legally accountable

The immigration system functions in relation to oversight must depart from a good service system and be supported by appropriate legal system tools, both from the traffic aspect of the entry of foreigners and in the administrative process of the foreigners' requirements. Substantially all three systems must be professionally executed when quality and proper supervision is expected, as in Figure 1 below:

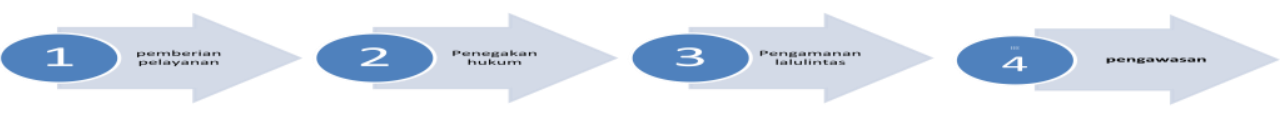

Figure 1. Four Immigration Nature

Although the immigration policy continues to be upgraded from the aspect of the rule if it is not supported by the correct personnel in carrying out its duties and functions then the rules or policy system will not proceed according to the expected goals and rules. The design of service rules, law enforcement, traffic security and oversight are not supported by a person's honesty so the rules will not go well. Therefore, a good system device should be supported with personnel, when policy rules are expected to work 
properly ${ }^{4}$. The problem can be analogous to the opinion of Zainal Abidin Farid in Achmad Ali $^{5}$, That it is better a bad system device but a good implementation system, if that's a matter of choice. But ideally better if good system device is also supported with good implementation. But the issue, about good systems and good practices, is rarely found in every institution including immigration.

Supervision is a fundamental thing in immigration holistically, either from the aspect of immigration services related to visa abuse and residence permit because there are still many personnel who play in immigration service. Apart from in-service games, there is also a lot of service for troubled foreigners such as visa and residence permits, in which the immigration personnel are always peaceful with the pay system which is then released. It is not in line with the nature of keimingrasian in terms of the nature and function of a multidimensional internally which is the aspect of ideology, politics, economy, social, culture, defense of national security, population, human resources and environment. While from the aspect of multidimensional internally is an aspect that is within the scope of the functions of immigration institutions such as; Service, law enforcement, establishment of law, organization and aspect of national development ${ }^{6}$.

The immigration service phenomenon that tends not to work prefesially because it still fulfills personnel games in the form of exploiting visa violations and residence permits as a way to generate a profit. Of these issues should the immigration authorities aware to further improve the behavior of structures within the internal immigration institutions in order not to become a culture in the space of immigration. Such problems internally in addition to injuring the immigration institution will also challenge the national resistance and more specifically, the issue will be more threatening to the Unitary State of the Republic of Indonesia.

The service dynamics that tend to be utilized by certain personnel to gain profit that will bias on the damaged image of Immigration institutions, and also become a culture and become threats of national and NKRI resistance, so the issue needs to increase strict supervision related to the process of servicing the various cases of foreigners, Especially the misuse of visas and residence permits. Therefore, speaking of supervisory issues is not only done within the scope of foreigners but also needs to be supervised on the process of service of foreigners related to the misuse of resident visas in order to avoid arrangement between the troubled stranger with the person of the Immigration personnel.

\footnotetext{
${ }^{4}$ Peter J. Spiro, "Federalism and immigration: Models and Trends." International Social Science Journal, 2001, hlm. 67-73,

${ }^{5}$ Achmad, Ali, 2002, Menguak Tabir Hukum Suatu Kajian Filosofis dan Sosiologis, Jakarta: PT. Yasrif Watampone, him. 10.

${ }^{6}$ M. Iman Santoso, lo.cit.,
} 


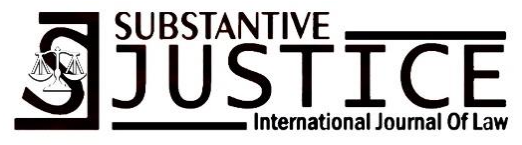

When a culture of peaceful rule grows in the space of immigration personnel it means the immigration authorities themselves provide opportunities for foreigners to commit offenses. The usual phenomenon of peaceful regulation of any issue in the body of immigration has indirectly undermined immigration laws and laws. Therefore, the supervisory function must be performed in all sub-sections of the immigration structure. In addition, in order to better maintain the independence and neutrality of immigration personnel so as not to be tempted by the compensation of the troubled foreigners, the personnel must be banned and kept away from the opportunity. To keep personnel away from the chances of bribery, in addition to avoiding personnel of the opportunity there is also no other way except for increased supervision.

As the theoretical observation theory put forward by Sujamto that conceptual oversight is any attempt or activity to know and assess the actual reality of the execution, task or occupation, whether appropriate or not. From the theory can be interpreted if the supervisory function not only applies to the supervision of the behavior of foreigners but also applies to the behavior of immigration personnel.

To be able to realize the principle of a selective policy ${ }^{7}$ Foreign control is required, this supervision is not only done when they enter but as long as they are located and their activities in the territory of Indonesia. Immigration control covers the areas of administrative immigration law enforcement as well as immigration crime. Immigration control is of course addressed to foreigners who enter the territory of Indonesia, document holders or without immigration documents are: a. Visit Permission; B. Limited Stay Permit; C. Permanent Stay Permit; and D. Without immigration documents / permits such as: a) Illegal Entry, eg illegal immigrants, refugees and asylum seekers; B) Illegal Stay, for example, resides in Indonesia exceeding the residence permit of immigration.

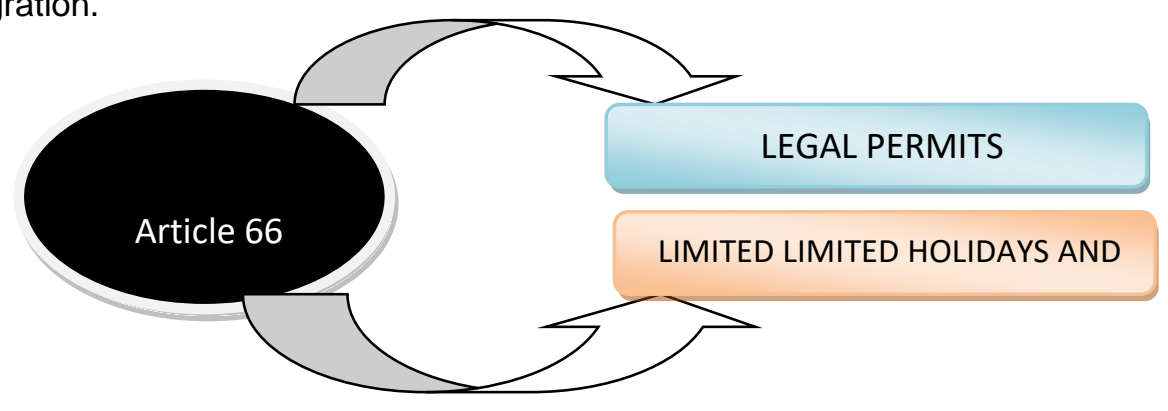

Figure 2. Oversight of the Stranger

${ }^{7}$ Kevin J. O'Brien \& Lianjiang Li. "Selective policy implementation in rural China." Comparative Politics, 1999, hlm. 167-186. 


\section{凫}

Therefore, the purpose of foreign control is to create security and stability from external threats, to provide security and order for Indonesian citizens and foreigners, to maintain a secure image to the outside world, to uphold the rule of law, including its activities. Implementation of foreign supervisory in practice has been carried out since the beginning of foreigners who will enter the territory of Indonesia through the Immigration Inspection (TPI) by conducting examination by conducting research on immigration documents (travel documents in the form of visas or passports) as well as checking block list, and Then the examination of Visiting Permit in the form of time objectives and then immigration also try to take preventive action (operative supervision) that is by doing thoroughly with all requirements on immigration documents Work Permit (if the concerned work) at the time of granting or display SKLD, Periodic examination of the completeness of the identity of foreigners, properly record the identity and activities of foreigners, and coordinate with relevant agencies.

The basic nature of the Immigration grip in carrying out its functions related to foreign controls and the misuse of visas and residence permits rests with Law no. 6 Year 2011 on Immigration. In addition, the other basis of which is the reference task and its function is in PP. 31 Year 2013 which is a translation of Law no. 6 Year 2011, Minister of Justice Decree No. RI. M.02_PW. 09. 02 of 1985 and the Implementation Guidance of the Director General of Immigration Number F-338.IL.01.10 OF 1995.

The figure below shows the basic nature of immigration control of a foreigner's freelance system, as follows:

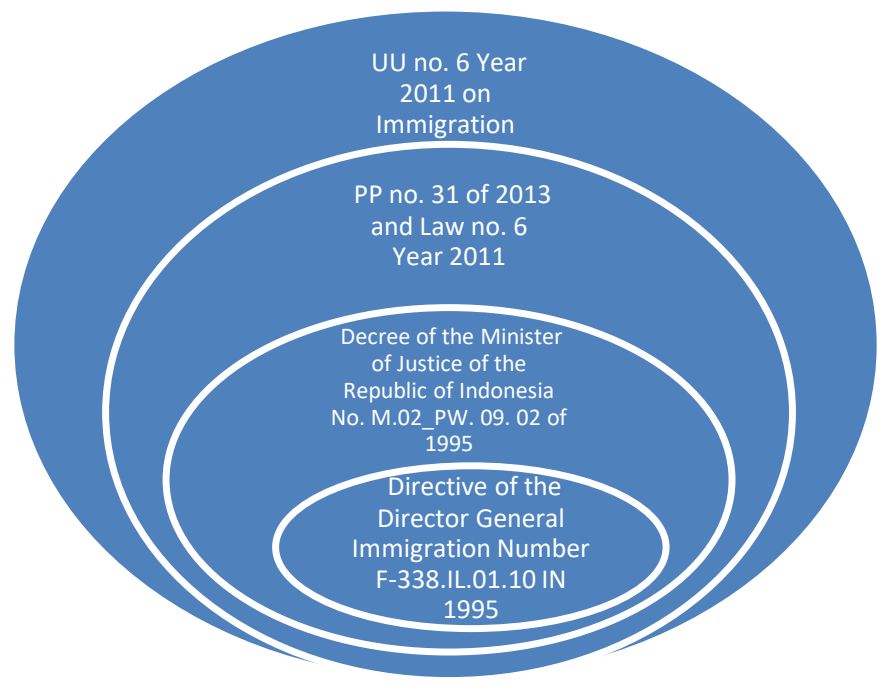

Figure 3. The Basic Nature of Oversight of Immigration System of Foreigners

Here are two things that have been targeted by foreigners in Indonesia, namely the supervision of their presence (immigratoir) and supervision on the activities of 
foreigners during their stay in Indonesia. The supervisory aspect of foreign activities requires a coordinated activity among agencies in terms of its oversight. The Minister of Justice as the Central Level Coordinator (national) together with other relevant governmental bodies or agencies as a coordinated oversight supervisor called the Coordination of Oversight of the Stranger. Basically the supervision of foreigners is the responsibility of the Minister of Justice and Human Rights in this case the immigration officials as the implementing operators. The mechanism of its implementation shall be carried out by coordinating with a government agency or agency whose field of duty concerns a foreigner, such agency or agency, among others, the Ministry of Foreign Affairs, the Ministry of Home Affairs, the Ministry of Defense and Security, the Ministry of Manpower, the Attorney General, the State Intelligence Agency and the State Police Republic of Indonesia. The Coordination of Overseas Supervision (SIPORA) is conducted in an integrated manner and SIPORA is established at the central, provincial and local levels.

\section{Embodiments of the Sovereignty of the Republic of Indonesia in the Field of Immigration}

Generally accepted views of the terms "sovereignty" and "sovereign" derived from Latin from the word "superanus" which means above. The term is derived from Latin Latin Classical with the presumption "super" which means above and the adjective is superus and superbus. From the Latin Latin, the original of the word superanus was transferred in early Franciscans in the form of the adjective so (u) verain (sovrain, sobrain) and as the noun so $(u)$ verainete (sovrainetez $)^{8}$

Raia Prokhovnik wrote that:

Some of the general features highlighted in the mainstream political theory discourse include the authority relationship between rulers and ruled; sovereignty as a recognition concept, relying upon the recognition of others in order to be established; sovereignty as a regulative ideal establishing political order and stability; sovereignty as a way of designating the 'whole' realm of a political unit; sovereignty as functional rather than territorial; and modern sovereignty establishing a modern constitutional state but also possibly overridden by the constitution. ${ }^{9}$

According to J.H.W. Versijl that sovereignty is "the power of the state", ${ }^{10}$ atau kekuasaan negara. Statement J.H.W. Versijl is based on a general observation that:

${ }^{8}$ Gerard Kreijn, 2004, State Failure, Sovereignty and Effectiveness: Legal Lessons from the Decolonization of Sub-Saharan Africa, Leiden: Martinus Nijhoff Publishers, hlm. 27.

${ }^{9}$ Raia Prokhovnik, 2008, Sovereignty: History and Theory, United Kingdom: Imprint Academic, hlm. 20.

${ }^{10}$ JimlyAsshiddiqie, 2011, Konstitusi dan Konstitusialisme Indonesia, Edisi Kedua, Jakarta: Sinar Grafika, hlm. 28. 
First, sovereignty is always associated with power. In modern doctrine, this power is the power / authority of the law, fundamentally souvereignty is identified with legal competence; Second, sovereignty is the power of the State; Third, sovereignty is the power of the state to act within the limits of state law (souvereignty is the power of the state to act within the limits of the law of nations) ${ }^{11}$

Sovereignty is the absolute and eternal power of an infinite and indivisible state.. ${ }^{12}$ Furthermore, in its development, the theory of sovereignty is developed into two distinct ideologies. On the one hand it is still considered that sovereignty must be intact (monism of sovereignty), while on the other hand there arises and develops a view which assumes that sovereignty in addition must not be lost, but Sovereignty Itself in its implementation will be limited by the rules applicable in relations between States (ideology pluralism sovereignty).

Formally sovereignty signifies the existence of a certain quality of the State (or legal order of the State) which in principle differs from other communities in such a way that the State may be qualified as the subject of international law.. ${ }^{13}$

The purpose of the sovereignty of the state as stated in the Preamble of the 1945 Constitution of the Republic of Indonesia is to protect the whole Indonesian nation and the entire Indonesian blood sphere, in the field of immigration it can be seen that Immigration has the function of maintaining the state's security from the entry of unfamiliar foreigners. In addition, a country has sovereignty in the presence of several conditions or elements as long as the referral of the international community, the condition of a state that is the united, regional or territory, sovereign government and the recognition of other countries while the elements of a country that is There must be a resident, there must be territory, there must be supreme authority and ability to relate to other countries.

State sovereignty is understood to the extent to which a country has the authority to implement policies and activities within its territory in order to implement its national law The sovereignty of a country as a concept of international law has three main aspects ${ }^{14}$ Namely: external, internal and territorial (territorial). The territorial aspect of sovereignty is the sole and total authority exercised by the state against all persons and objects located above, below or above the air of the territory.

\footnotetext{
${ }^{11}$ Gerard Kreijn State Failure, Sovereignty... op.cit., hlm 28-29.

12 Andrew Vincent, 1987, Theories of The State, Oxford: Basil Blackwell, hlm. 14.

${ }^{13}$.G.Starke, 1989 An Introduction to International Law, Tenth Edition, London, Butterworth \& Co., Ltd., hIm. 157158.

${ }^{14}$ Yudha Bhakti Ardhiwisastra, 1999, Imunitas Kedaulatan Negara Di Forum Pengadilan Asing. Jakarta: Alumni, hlm. 21.
} 
It is the right of every State to exercise its jurisdiction over its territory and of all persons and property therein, except to the immunities recognized in international law. The right of a country's jurisdiction is a reflection of the obligation of other states not to exercise its jurisdiction within the territory except with the permission of that country.

In 1992 the Immigration Act was passed, namely Law Number 9 of 1992, so that all matters relating to Immigration and all other implementing regulations such as government regulations, presidential decrees, ministerial decrees, and related ministerial decisions and other officials are regulated On the Act. Considered that the law is not yet perfect, then the new Law was published in 2011 that is Law Number 6 Year 2011 on Immigration.

All government provisions and policies under this law will always be based on a selective, rather than open, corridor of immigration policy aimed at protecting national interests and emphasizing the principle of protection of Indonesian citizens. Based on this principle foreigners are given entry and residence if they benefit the welfare of the people and do not endanger the security, public order.

The concept of Sovereignty establishes that a state has power over a territory (territorial rights) as well as rights which subsequently arise from the use of such territorial powers in the sense that the state has the full power to exercise its territorial rights within the territorial boundaries of the country concerned.

Important aspect embodied in sovereignty is the concept of jurisdiction or authority and authority for traffic control of persons entering, leaving and staying from and into the territory of the Republic of Indonesia is the authority of Immigration, where in this case the authority of immigration is a manifestation of the sovereignty of the state which is poured In the form of People Traffic Control and Immigration Control against Strangers in the Jurisdiction of the Republic of Indonesia.

The established immigration procedure is the operationalization of a selective policy of immigration law so that foreigners residing in Indonesia have limitations both in terms of their immigration clearance and their activities. Immigration Control includes immigration law enforcement where in the implementation of immigration task the whole rule of immigration law is upheld to every person who is in the jurisdiction of the Republic of Indonesia whether it is Indonesian Citizen or Foreigner .

Based on the sovereignty of a country, the authority it possesses includes legislative authority, administrative authority and judicial authority. In its development these three authorities are recognized as three jurisdictional environments namely :

a) Jurisdiction to prescribe 
It is the authority of the state to enact a law and to enact a national law against a crime that endangers the interests of the state or the citizen concerned.

b) Jurisdiction to adjudicate

It is the authority of the state to carry out prosecutions and prosecute crimes that endanger the interests of the state or the citizens concerned.

c) Jurisdiction to enforce

It is the authority of the state to apply the national legislation to those endangering the interests of the state or the citizens concerned.

Within the framework of International relations the problems of state jurisdiction can arise in the international community because each country is a sovereign member, and in addition the prevailing relations within the international community take place through theboundariesofacountry. Relevant to that in implementing the Immigration function, especially the function of state security, immigration acts as the gatekeeper of the state, because immigration is the first and last institution that filters the arrival and departure of foreigners to and from the territory of Indonesia, the function of immigration along the border area of Indonesia Is the authority of the immigration authorities and is carried out by the Immigration Official which covers the Immigration Check (TPI) and cross-border post.

The state is said to be sovereign or sovereign because sovereignty is an essential trait or characteristic of the state. The ultimate sovereignty rests with the state, but this supreme power has its limits, the highest administrative sphere is limited by the borders of the country, meaning a state has only the highest authority within its borders.

Traffic arrangements of people entering or leaving the territory of Indonesia is a strategic governmental function in international relations and at the same time placing the sovereignty of the State in a balanced way. Based on these provisions, the function and role of immigration law of Indonesia covers the national and international aspects as the implications of the existence of the sovereignty of the Republic of Indonesia and the legal state based on Pancasila and the Republic of Indonesia Year 1945.

Implementation of the person's traffic arrangement is a derivation from the state to grant permission or prohibit foreigners from entering into their territory and is an essential attribute of the sovereign government. Therefore a foreigner entering the territory of Indonesia must be subject to Indonesian immigration

Immigration serves as a guardian of the gate of state sovereignty. It is said that because immigration is the first and last institution that filters and selects the arrival and departure of foreigners to the territory of the Republic of Indonesia. The authority of the Directorate General (DG) of Immigration, Ministry of Justice and Human Rights 


\section{凫}

(Kemenkumham) is very significant in the context of maintaining the sovereignty of the state.

Law No. 6 of 2011 on Immigration authorizes the Directorate General of Immigration to conduct supervision, regulation and law enforcement to persons entering and leaving the territory of the Republic of Indonesia at the gate of the State which includes, Airports (Airport), seaports, and land borders At the State Border Post.

\section{CONCLUSION}

The nature of immigration control over the misappropriation of visas and residence permits in Indonesia in the framework of operationalization of a selective policy of immigration law so that foreigners residing in Indonesia have limitations both in terms of their immigration clearance and their activities. The nature of oversight is also in order to uphold the sovereignty of the Republic of Indonesia as a jurisdiction, namely: jurisdiction to prescribe, jurisdiction to adjudicate and jurisdiction to enforce. Basically the main objective of foreign control is to protect the people and the sovereignty of the State. Foreigners who do not bring benefits and can jeopardize order should be prevented from entering Indonesian territory.

\section{REFERENCE}

Achmad Ali. 2002. Menguak Tabir Hukum Suatu Kajian Filosofis dan Sosiologis, Jakarta: PT. Yasrif Watampone.

2002. Keterpurukan Hukum di Indonesia: Penyebab dan Solusinya, Jakarta: Ghalia Indonesia.

Andrew Vincent. 1987. Theories of The State. Oxford: Basil Blackwell.

Anonimous, "Immigration Donate 1.8 Trillion Throughout 2013" http://www.imigrasi.go.id/index.php/berita/berita-utama/365-rilis-ditjen-imigrasiawaltahun-2014diakses pada 12 Juni 2017

Awaloeddin Djamin. 2000. Administrasi Kepolisian RI Menghadapi Tahun 2000, Lembang: Sanyata Sumasana Wira.

Bibit Samad Rianto. 2006. Pemikiran menuju Polri yang Profesional, Mandiri, Berwibawa, dan Dicintai Rakyat. Jakarta: PTIK Press. 


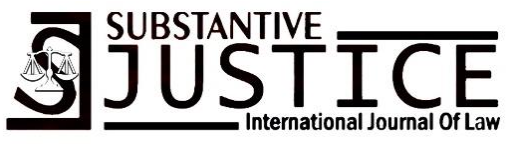

Volume I, Issue 1, March 2018 : 9 - 22

Desi Setiawati. "Penegakan Hukum Terhadap Warga Negara Asing (WNA) yang Melanggar Izin Tinggal (Overstay). Pandecta: Research Law Journal. Volume 10. No.1. 2015.

Edi Suwiknyo, "Isu Pekerja Asing, Jumlah WNA Masuk Indonesia 2016 Malah Turun",http://www.solopos.com/2017/01/15/isu-pekeria-asing-jumlah-wna-masukindonesia-2016-malah-turun-784686 diakses pada 12 Juni 2017

Gerard Kreijn. 2004. State Failure, Sovereignty and Effectiveness: Legal Lessons from the Decolonization of Sub-Saharan Africa. Leiden: Martinus Nijhoff Publishers.

Iman Santoso, M. 2004. Persfektif Imigrasi dalam Pembangunan Ekonomi dan Ketahanan Nasional. Jakarta: Universitas Indonesia Press.

JimlyAsshiddiqie. 2011. Konstitusi dan Konstitusialisme Indonesia, Edisi Kedua, Jakarta: Sinar Grafika.

Kevin J. O'Brien \& Lianjiang Li. "Selective policy implementation in rural China." Comparative Politics. 1999.

Muhammad Indra, .Perspektif Penegakan Hukum dalam Sistem Hukum Keimigrasian Indonesia., Disertasi, Program Doktor Pasca Sarjana Universitas Padjadjaran, Bandung, 23 Mei 2008.

Peter J. Spiro, "Federalism and immigration: Models and Trends." International Social Science Journal 53.167. 2001.

Raia Prokhovnik. 2008. Sovereignty: History and Theory, United Kingdom: Imprint Academic.

Sedarmayanti \& Syarifudin Hidayat. 2002. Metodologi Penelitian, Bandung: Mandar Maju.

Soejono dan H. Abdurahman. 2003. Metode Penelitian Hukum. (Jakarta: Rineka Cipta.

Sonny Keraf, A. \& Mikhael Dua. 2001. Ilmu Pengetahuan (Sebuah Tinjauan Filosofis), Yogyakarta: Kanisius.

Starke, G. 1989. An Introduction to International Law. Tenth Edition. London: Butterworth \& Co., Ltd.

Yudha Bhakti Ardhiwisastra. 1999. Imunitas Kedaulatan Negara Di Forum Pengadilan Asing. Jakarta: Alumni 